\title{
Variations of soil water isotopes and effective contribution times of precipitation and throughfall to alpine soil water, in Wolong Nature Reserve, China
}

\author{
Yuhong Liu ${ }^{\text {a,e,f,1 }}$, Fude Liu ${ }^{\mathrm{b}, 1}$, Zhen $\mathrm{Xu}^{\mathrm{c}}$, Jianping Zhang ${ }^{\mathrm{d}}$, Lixin Wang ${ }^{\mathrm{e}, *}$, Shuqing $\mathrm{An}^{\mathrm{f}}$ \\ a Yantai Institute of Coastal Zone Research, CAS, Yantai 264003, China \\ b School of Environmental Science and Safety Engineering, Tianjin University of Technology, Tianjin 300384, China \\ c State Power Environmental Protection Research Institute, Nanjing 210031, China \\ d Chongqing Institute of Meteorological Sciences, Chongqing 401147, China \\ e College of Environment and Resources, Inner Mongolia University, Hohhot 010021, China \\ ${ }^{\mathrm{f}}$ Laboratory of Forest Ecology and Global Changes, School of Life Science, Nanjing University, Nanjing 210093, China
}

\section{A R T I C L E I N F O}

Article history:

Received 14 May 2014

Received in revised form 15 September 2014

Accepted 12 November 2014

Available online $\mathrm{xxxx}$

\section{Keywords:}

Alpine shrubland

Interflow

Rainy season

Stable hydrogen isotope

Stable oxygen isotope

\begin{abstract}
A B S T R A C T
Alpine shrubs and soils in catchments of the headwaters of the Yangtze River in west China are very important for reducing flooding and sustaining base flow during the summer. However, the contributions of precipitation, throughfall, and interflow to soil water and their effective contribution times in alpine shrub soil are not fully understood. In this study, we investigated a time series of stable isotopes in soil water, precipitation, canopy throughfall, interflow, litter, and humus water in a hillslope area. In addition, the spatial variation of water isotopes in soil profile in the Wolong Valley, located in the upper watershed of the Yangtze River, Sichuan, China, was considered. We found that (1) precipitation and throughfall significantly affected water isotopes in litter, humus, and shallow soil ( $0 \mathrm{~cm}$ to $50 \mathrm{~cm}$ deep) by affecting preferential flows. (2) Rainwater from a small precipitation event (about $4.0 \mathrm{~mm} \mathrm{~d}^{-1}$ ) also penetrated soil to depths of $40 \mathrm{~cm}$ to $50 \mathrm{~cm}$. (3) Interflow could comprise as much as $96 \%$ of water in soil columns during non-rainy days, but the proportion would decrease quickly after the precipitation amount reached more than $3 \mathrm{~mm} \mathrm{~d}^{-1}$. (4) Mean effective contribution times of recharge in soil ( $0 \mathrm{~cm}$ to $50 \mathrm{~cm}$ deep) occurred 3 to 5 days despite the occurrence of large precipitation events $(15.0 \mathrm{~mm}$ and $18.9 \mathrm{~mm}$ ). Therefore, preferential flows composed of precipitation/throughfall and interflow were dominant in hillslope hydrology in the southeast edge of Tibet, which caused runoff to increase during the rainy season.
\end{abstract}

(c) 2014 Elsevier B.V. All rights reserved.

\section{Introduction}

Shallow soil water serves as an important reservoir in the hydrological cycle (Gat, 1996) and is a primary water source for most plants (Ehleringer et al., 2000) and a solvent of numerous nutrients (Gazis and Feng, 2004). The isotopic compositions of hydrogen and oxygen remain stable in water and are geochemically conservative, allowing them to be used as natural tracers of water recharged by different storms (Acheampong and Hess, 2000; Ehleringer et al., 2000; McGuire et al., 2002). Stable isotopes of water can likewise be used to characterize the way in which subsurface water mixes (Carreon-Diazconti et al., 2003), the extent of soil water recharge (Cane and Clark, 1998; Girard et al., 1997) and flow mechanisms in soil (Asano et al., 2002; Gazis and Feng, 2004). In addition, they can be used to measure different water residence time (Asano et al., 2002; Landon et al., 2000; Rosen

\footnotetext{
* Corresponding author.

E-mail addresses: yu_hong_liu@263.net (Y. Liu), lx_wimu@163.com (L. Wang).

${ }^{1}$ Yuhong Liu and Fude Liu is co- first author.
}

et al., 1999), the degree of water uptake of plants (Cheng et al., 2006), and the amount of evapotranspiration occurring in an area (Hsieh et al., 1998; Ridolfi et al., 2003; Wang and Yakir, 2000).

In general, rainwater enters soil by diffusive, piston, and preferential flows. Diffusive recharge usually occurs in unsaturated soil. In contrast, piston flow moves as a "front" of water down a hydraulic gradient when precipitation rates are high. Under piston flow, water from recent precipitation events forces older residual soil water downwards and often mixed with old soil water (Asano et al., 2002; Gazis and Feng, 2004). Piston flow can be documented based on stable isotope characteristics of soil water when precipitation events have different temporal and meteorological sources. Preferential flows may exist in saturated and unsaturated conditions through macropores caused by cracks, decayed plant roots, earthworm burrows, rocks, etc. (Dusek et al., 2012; Gazis and Feng, 2004). High-intensity rain events could contribute to higher amounts of preferential flow, and smaller rainfall events could arrive in deep soils through preferential flow paths (Stumpp and Maloszewski, 2010). Moreover, roles of preferential flow are complex in hillslope hydrology (Klaus et al., 2013), and the initiation 
of preferential flow depends on the boundary and initial conditions of soil (Ghodrati et al., 1999; Langner et al., 1999; Lennartz and Kamra, 1998; Seyfried and Rao, 1987). Isotopic profiles in soil can be used to obtain proportional contributions of multiple water sources, to identify whether diffusive, piston, or preferential flow dominates recharge and to determine the water sources of different precipitation events (Gazis and Feng, 2004).

Water isotopes have been used in the analysis of hillslope hydrology to obtain information on residence time of soil water (DeWalle et al., 1997) and soil moisture patterns (McDonnell and Buttle, 1998; Ridolfi et al., 2003). They have also been used in the analyses of storm runoff components (Brown et al., 1999), preferential flow paths (Weiler and McDonnell, 2004), intercomparison of hillslopes and catchments (Uchida et al., 2005, 2006), and transit time and modeling (McGuire and McDonnell, 2006; McGuire et al., 2007). However, upstream catchments of the Yangtze River in west China are very important in reducing floods and in sustaining base flow during summer. Therefore, understanding how water recharge occurs in soil in these catchments during the rainy season is necessary for managers of river water resources.

In the Balang Mountain region within Wolong Nature Reserve, located in the upper watershed of the Yangtze River, a typical vegetation type, alpine shrub, plays an important role in controlling floods and in sustaining base flow (Liu et al., 2011a, 2011b). Therefore, determining effective contribution times of precipitation and throughfall to soil water in the alpine shrub ecotype during the rainy season is important. However, presently, few studies have investigated this topic in this region. The aim of this study is to analyze the characteristics of stable isotopes in precipitation, throughfall, interflow, and water in litter, humus, and different soil layers in a hillslope area. These data are then used to estimate the contributions of precipitation, throughfall, and interflow to soil water, and to calculate their effective contribution times in different soil layers.

\section{Materials and methods}

\subsection{Study sites}

The study site was established on Balang Mountain in Wolong Nature Reserve in Minjiang Valley. The Reserve lies in Wenchuan County, Sichuan Province, China, and features a subhumid temperate zone climate. The westerly wind circulation from November to March alternately influences the weather with the southeast monsoon from April to August and the southwest monsoon from September to October. The rainy season extends from May to October and more than $50 \%$ of precipitation events occur at rates of $<5 \mathrm{~mm} \mathrm{~d}^{-1}$, while only about $10 \%$ are $>15 \mathrm{~mm} \mathrm{~d}^{-1}$ (Li et al., 2006). Mean annual precipitation, actual evaporation, relative humidity, and temperature are $711 \mathrm{~mm}, 545 \mathrm{~mm}$, $80 \%, 8.9{ }^{\circ} \mathrm{C}$, respectively (Wolong Nature Reserve Administration Bureau (WNRAB), 1987).

Quercus aquifolioides, a representative survivor of semi-arid or arid flora of the ancient Tethys Ocean, dominates the south-facing slopes of Balang Mountain from an elevation of 2,700 $\mathrm{m}$ to 3,600 $\mathrm{m}$. The vegetation community has two layers, the shrub and herb layers, with coverage of more than $90 \%$. Coverage of $Q$. aquifolioides generally ranges from $60 \%$ to $80 \%$, and herb coverage is less than $15 \%$ (WNRAB, 1987).

Three $10 \mathrm{~m} \times 10 \mathrm{~m}$ plots (Fig. 1 ) were selected on the southeast (SE) slope of Balang Mountain, including Plot A (elevation 3,070 m; $30^{\circ} 51.810^{\prime} \mathrm{N}, 102^{\circ} 58.147^{\prime} \mathrm{E}$ ), Plot B (elevation $2,930 \mathrm{~m} ; 30^{\circ} 51.845^{\prime} \mathrm{N}$, $102^{\circ} 58.286^{\prime} \mathrm{E}$ ), and Plot C (elevation $2,830 \mathrm{~m} ; 30^{\circ} 51.782^{\prime} \mathrm{N}, 102^{\circ} 58.364^{\prime}$ E). Two seeps of interflow on the slope, identified here as SI (elevation $3.030 \mathrm{~m} ; 30^{\circ} 51.845^{\prime} \mathrm{N}, 102^{\circ} 58.171^{\prime} \mathrm{E}$ ) and SII (elevation $2,790 \mathrm{~m}$; $30^{\circ} 51.850^{\prime} \mathrm{N}, 102^{\circ} 58.531^{\prime} \mathrm{E}$ ) (Fig. 1), were also selected on the SE slope of the mountain for this study. Interflow on seeps occurred throughout the rainy season. Q. aquifolioides covers the hillslope. Mountain brown soil covers the slope to a depth of usually about $50 \mathrm{~cm}$ from an elevation of 2,800 to 3,100 m. Humus depth is less than $5 \mathrm{~cm}$, and litter thickness varies from $2 \mathrm{~cm}$ to $5 \mathrm{~cm}$. Table 1 provides parameters of soil hydrology at the study site.

\subsection{Field sampling}

Meteorological data were obtained from the Wolong Ecological Station (WES), about $500 \mathrm{~m}$ away from Plot $\mathrm{C}$ and located outside the vegetation area, and from an automatic weather station, less than $50 \mathrm{~m}$ away from Plot $\mathrm{C}$ and located within the vegetation area. The WES measured amounts of precipitation and evaporation outside the vegetation area while the automatic weather station monitored evaporation within the vegetation area.

A rain gauge located in WES collected precipitation from events $>3 \mathrm{~mm} \mathrm{~d}^{-1}$ from August 9 to 20, 2003, and precipitation on consecutive days was treated as one precipitation event (Table 2). Canopy throughfall samples were collected from three containers placed around tree trunks with a radius of $0.16 \mathrm{~m}$ in Plots A, B, and C from August 9 to 20, 2003 (nine containers in this study). In each plot, throughfall water samples from the three containers were combined into a single sample (Table 2). Interflow samples were collected from two slope seeps from August 10 to 14 and August 16 to 20, 2003. A total of four precipitation, 12 throughfall, and 20 interflow samples were collected.

Soil samples were collected at $0-5 \mathrm{~cm}, 5-10 \mathrm{~cm}$, and at $10 \mathrm{~cm}$ intervals from $10 \mathrm{~cm}$ to $50 \mathrm{~cm}$ at the three plots by soil auger. Humus and litter samples were collected within about 1 meters of each soil profile. Samples named Soil 1, 2, 3, 4, 5, and 6 came from depths of 0-5, 5-10, $10-20,20-30,30-40$, and $40-50 \mathrm{~cm}$, respectively. Samples of litter, humus, and Soils 3 and 6 were collected from August 10 to 14 and from August 16 to 20, 2003. Soils 1, 2, 4, and 5 were collected on August 13, 16, and 20, 2003. In total, 30 humus, 30 litter, and 96 soil samples were collected from the three plots.

Field collection was conducted before 10 am on each sampling day to reduce the influence of evaporation and transpiration. All samples were placed in $10 \mathrm{~mL}$ Pyrex tubes, sealed with plastic septum and Parafilm ${ }^{\circledR}$, and stored at $-15^{\circ} \mathrm{C}$. Additional soil samples were collected on July 25, 2003 (before the sampling period) and August 25, 2003 (after the sampling period), dried at $105{ }^{\circ} \mathrm{C}$ for $48 \mathrm{~h}$, and weighed to estimate the soil water content.

\subsection{Stable isotopic analysis}

Water was extracted from soil samples by cryogenic vacuum distillation (Ehleringer et al., 2000) and analyzed for hydrogen and oxygen isotopes using a continuous flow isotope ratio mass spectrometer coupled with a thermal conversion/elemental analyzer (MAT-253, Thermo-Finnigan Instruments, Germany). Results were reported as parts per mil (\%) with respect to Vienna standard mean ocean water (VSMOW) using the $\delta$ notation:

$\delta_{\text {sample }}=\left(R_{\text {sample }}-R_{\text {standard }}\right) \ddot{\mathbf{E}} 1000 / R_{\text {standard }}$,

where $\delta_{\text {sample }}$ is the isotope ratio of the sample relative to the VSMOW,

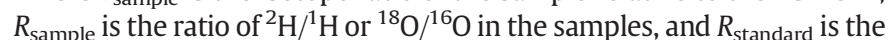
ratio of ${ }^{2} \mathrm{H} /{ }^{1} \mathrm{H}$ or ${ }^{18} \mathrm{O} /{ }^{16} \mathrm{O}$ in the VSMOW. Analytical precision is $2.0 \%$ of $\delta \mathrm{D}$ and $0.1 \%$ ofor $\delta^{18} \mathrm{O}$.

\subsection{Data analysis}

Based on mass balance equations, proportional contributions of $(n+1)$ sources can be uniquely determined through the use of $n$ different isotope system tracers when mixing is assumed to be linear (Phillips and Gregg, 2003). When the number of potential sources 

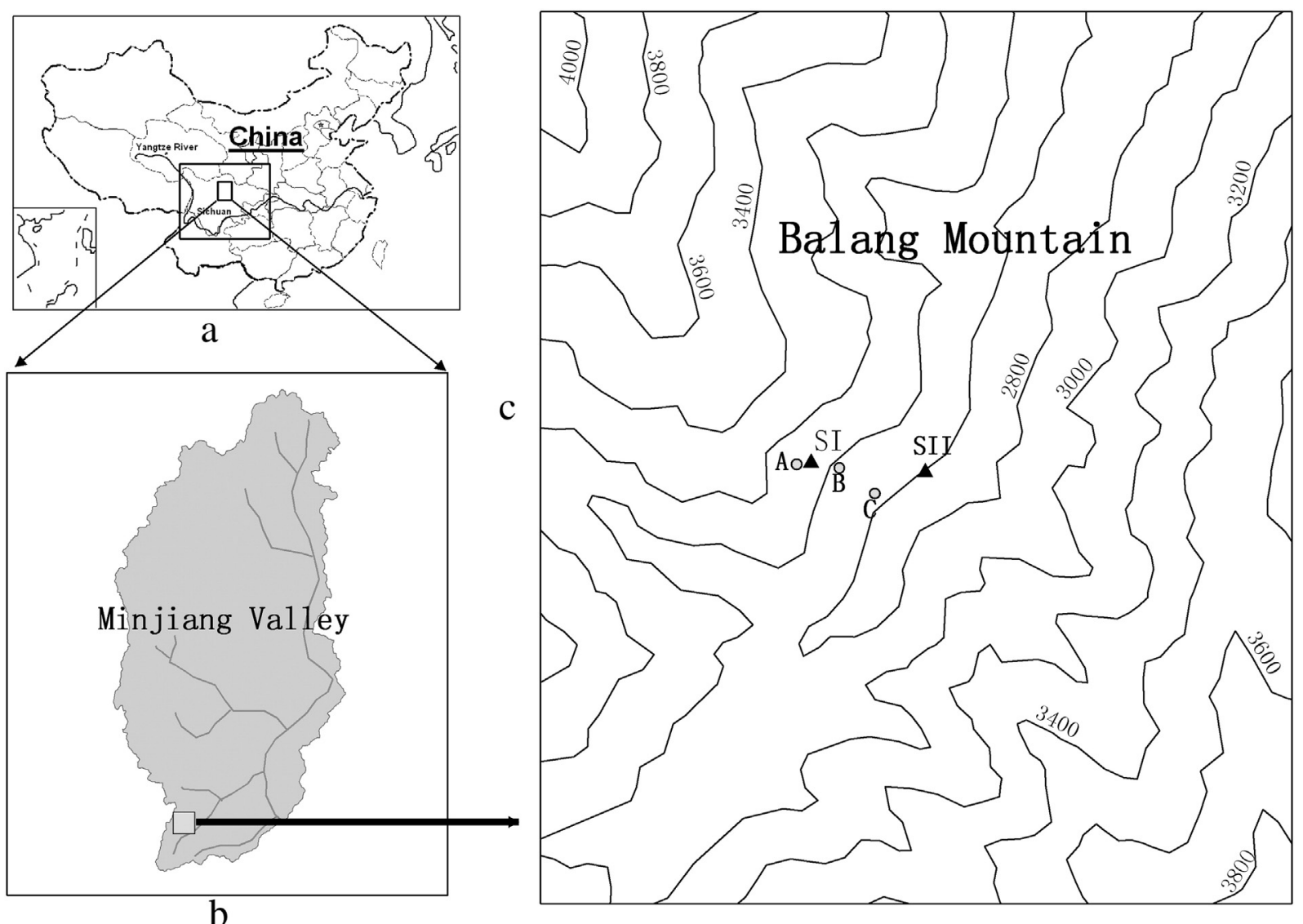

Fig. 1. Locations of sampling sites, including Plots A, B, and C, and slope seeps SI and SII in Balang Mountain, Minjiang Valley.

exceeds $(n+1)$, unique source proportions are difficult to obtain (Phillips and Gregg, 2001, 2003).

As a solution, Phillips and Gregg (2003) proposed the IsoSource model to quantify bounds of the contributions of multiple sources. In this method, all possible combinations of each source contribution $(0 \%$ to $100 \%$ ) are examined in small increments (e.g., $1 \%$ ). When combinations total to the observed mixture's isotopic signatures within a small tolerance (e.g., $0.1 \%$ ), these combinations are considered to be feasible solutions, from which the frequency and range of potential source contributions can be calculated (Phillips and Gregg, 2003). Based on Eq. 2 and the IsoSource model,

$\delta \mathrm{s}_{\mathrm{M}}=\mathrm{f}_{\mathrm{s}} * \delta_{\mathrm{s}}+\mathrm{f}_{\mathrm{p}} * \delta_{\mathrm{p}}+\mathrm{f}_{\mathrm{t}} * \delta_{\mathrm{t}}+\mathrm{f}_{\mathrm{i}} * \delta_{\mathrm{i}}$

$1=\mathrm{f}_{\mathrm{s}}+\mathrm{f}_{\mathrm{p}}+\mathrm{f}_{\mathrm{t}}+\mathrm{f}_{\mathrm{i}}$.

We used isotopic values of soil samples before August 9-10 as preevent water $\left(\delta_{s}\right)$ and isotopic values of precipitation $\left(\delta_{p}\right)$, throughfall $\left(\delta_{\mathrm{t}}\right)$, and interflow $\left(\delta_{\mathrm{i}}\right)$ as event waters of soil water mixtures $\left(\delta \mathrm{s}_{\mathrm{M}}\right)$. These soil water mixtures were average isotopic values of soil samples from the same layer of three plots on the same day after August 10. In this study, we set the contribution increment of each source at $1 \%$ and the tolerance of the sum at $0.1 \%$. Next, $\delta$ values were input into the IsoSource model to calculate contributions $(f)$ of different types of water such as precipitation, throughfall, and interflow at different times (August 11 to August 20) to the mixtures collected from humus, Soil 3, and Soil 6 . When the mean contribution of precipitation, throughfall, and interflow to soil water on a particular day of August 11 to August 20 in this model was less than $5 \%$, the distribution of feasible solutions was close or equal to zero, which meant that the contribution effect of this event water vanishes from soil water. Therefore, we assumed the times (the time of a particular day-August 10) obtained from this calculation were the effective contribution times of water source to soil water, which were used to describe the extent to which precipitation and throughfall affect soil water during the rainy season.

Repeated ANOVA measures were used to test the temporal dynamics of soil water content, and temporal and spatial dynamics of the isotopic values of litter, humus, and soil water. In the ANOVA, data from the same layer of the three plots on the same day were treated as repeated measures, and then Mauchly's test of sphericity was used to

Table 1

Soil hydrology parameters in study plots, including capillary porosity (CP), non-capillary porosity (NCP), steady infiltration rate (IR), bulk density (BD), percent gravel, and texture.

\begin{tabular}{|c|c|c|c|c|c|c|}
\hline \multirow[b]{2}{*}{ Soil depth $(\mathrm{cm})$} & \multicolumn{6}{|c|}{ Soil hydrology parameters* } \\
\hline & $\mathrm{CP}(\%)$ & $\mathrm{NCP}(\%)$ & $\mathrm{IR}(\mathrm{mm} / \mathrm{min})$ & $\mathrm{BD}\left(\mathrm{g} / \mathrm{cm}^{3}\right)$ & Gravel (\%) & Texture \\
\hline $0-20$ & $44.3 \pm 6.5$ & $4.3 \pm 0.1$ & $8.0 \pm 0.8$ & $0.8 \pm 0.1$ & $20-30$ & Silt loam clay \\
\hline $20-40$ & $56.0 \pm 13.0$ & $2.3 \pm 0.2$ & $6.0 \pm 1.0$ & $1.0 \pm 0.2$ & $20-40$ & Silt loam clay \\
\hline $40-50$ & $39.5 \pm 2.0$ & $2.1 \pm 0.4$ & $3.6 \pm 0.4$ & $1.1 \pm 0.1$ & $30-50$ & Loam clay \\
\hline
\end{tabular}


Table 2

Measures of sampling date, water isotope values, and collection amount of precipitation and canopy throughfall. Consecutive precipitation occurred on August 9 to 10, 2003.

\begin{tabular}{lllll}
\hline Source & Collection date & $\delta \mathrm{D}(\%)$ & $\delta^{18} \mathrm{O}(\%)$ & Amount $(\mathrm{mm})$ \\
\hline \multirow{2}{*}{ Precipitation } & August 9-10, 2003 & -84.4 & -10.5 & 18.9 \\
& August 11, 2003 & -68.2 & -8.6 & 4.0 \\
& August 13, 2003 & -75.5 & -9.9 & 6.6 \\
\multirow{5}{*}{ Throughfall } & August 15, 2003 & -82.2 & -9.9 & 15.0 \\
& August 9-10, 2003 & $-83.2 \pm 0.7$ & $-10.8 \pm 0.3$ & $17.6 \pm 1.1$ \\
& August 11, 2003 & $-71.1 \pm 1.5$ & $-9.2 \pm 0.2$ & $3.3 \pm 0.3$ \\
& August 13, 2003 & $-81.3 \pm 4.0$ & $-10.2 \pm 0.1$ & $4.7 \pm 0.6$ \\
& August 15, 2003 & $-91.9 \pm 2.2$ & $-11.1 \pm 0.7$ & $13.5 \pm 1.2$ \\
\hline
\end{tabular}

evaluate relationships among repeated measures of different times. Correlations between isotopic values of water and evaporation amount were tested by Kendall correlation analysis (bivariate process). All statistical analyses were conducted using the software package SPSS 16.0 for Windows.

\section{Results}

\subsection{Temporal and spatial variations of volumetric water content in the soil profile}

Average volumetric water content ranged from 0.39 to 0.74 in the litter and humus layers, and from 0.25 to 0.49 in the soil layers on July 25 and August 13, 16, 20, and 25 (Fig. 2). Significant differences existed in water content across 5 days $(p<0.05)$. Water content was likewise affected by measured time and layer locations $(p<0.05)$. No significant difference existed in water content across 5 days in each layer of Soil 3 to Soil 6 (all $p>0.05$ in LSD comparison), and except on August 16, water content was similar in humus, Soil 1, and Soil 2 (all $p>0.05$ in LSD comparison). Therefore, water content of each layer in the soil profile was stable during small rain events.

\subsection{Temporal dynamics of soil water isotopes during different rain events}

Significant temporal variations of $\delta \mathrm{D}$ and $\delta^{18} \mathrm{O}$ were found in the litter and humus layers $(p<0.05)$, whereas no significant variation occurred in any soil layer during the sampling period $(p>0.05)$ (Fig. 3).
Daily evaporation and $\delta \mathrm{D}$ or $\delta^{18} \mathrm{O}$ values of litter water were poorly correlated ( $r=0.295, p=0.014$ and $r=0.046, p=0.366$, respectively), and a similar phenomenon existed between evaporation and $\delta \mathrm{D}$ or $\delta^{18} \mathrm{O}$ values of humus water $(r=0.117, p=0.193$ and $r=0.167, p=$ 0.112 , respectively). However, water isotopes of litter and humus water were affected by evaporation on the slopes of the fitting line of humus and litter water less than the local meteoric water line (Fig. 4); therefore, statistical methods were not suitable for evaluating the impact of evaporation on the isotopic values of humus and litter water in this study. Isotopic values of interflow were steady over the period $(p>0.05$; coefficient of variance $=1.7 \%, n=20)$, ranging from -80.5 to $-76.3 \%$ for $\delta \mathrm{D}$ and -11.2 to $-10.1 \%$ ofor $\delta^{18} \mathrm{O}$ (Fig. 3 ).

\subsection{Spatial variation of water isotopes in the soil profile}

Based on Fig. 5, isotopic profiles of $\delta \mathrm{D}$ and $\delta^{18} \mathrm{O}$ on August 13 and 20 were similar and different from that on August 16. This occurred because the water isotopic profile of August 16 was affected strongly by higher precipitation and throughfall on August 15, while an interval of several days existed between higher event water (on August 9-10 and 15) and soil sample collection on August 13 and 20. Fig. 4 shows evaporation significantly affected the water isotope values of litter and humus samples.

\subsection{Contributions of precipitation, throughfall, and interflow in the soil profile}

With regard to humus water, precipitation generally provided its contributing peak on the second day after precipitation events; contributions of throughfall were generally less than $20 \%$ (Fig. 6). Contributions of precipitation and throughfall to Soil 3 water were usually less than 15\% (Fig. 6b, c, and d), and contribution peaks were about 51\% (Fig. 6a) and $36 \%$ (Fig. 6d), respectively. Contributions of precipitation and throughfall in Soil 6 water included less than 33\% after small precipitation events (Fig. 6b and c), and at most 61\% after large precipitation events (Fig. 6a and d). Contributions of throughfall on August 11 and 13 were greater than those of precipitation events in Soil 3 and Soil 6 (Fig. 6b and c).

Interflow was also an important water source, including $21.1 \%$ to 95.6\% of water in Soil 3 and 24.3\% to 94.5\% of water in Soil 6 during dry days (Fig. 6e). When precipitation was $>3 \mathrm{~mm} / \mathrm{d}$, interflow

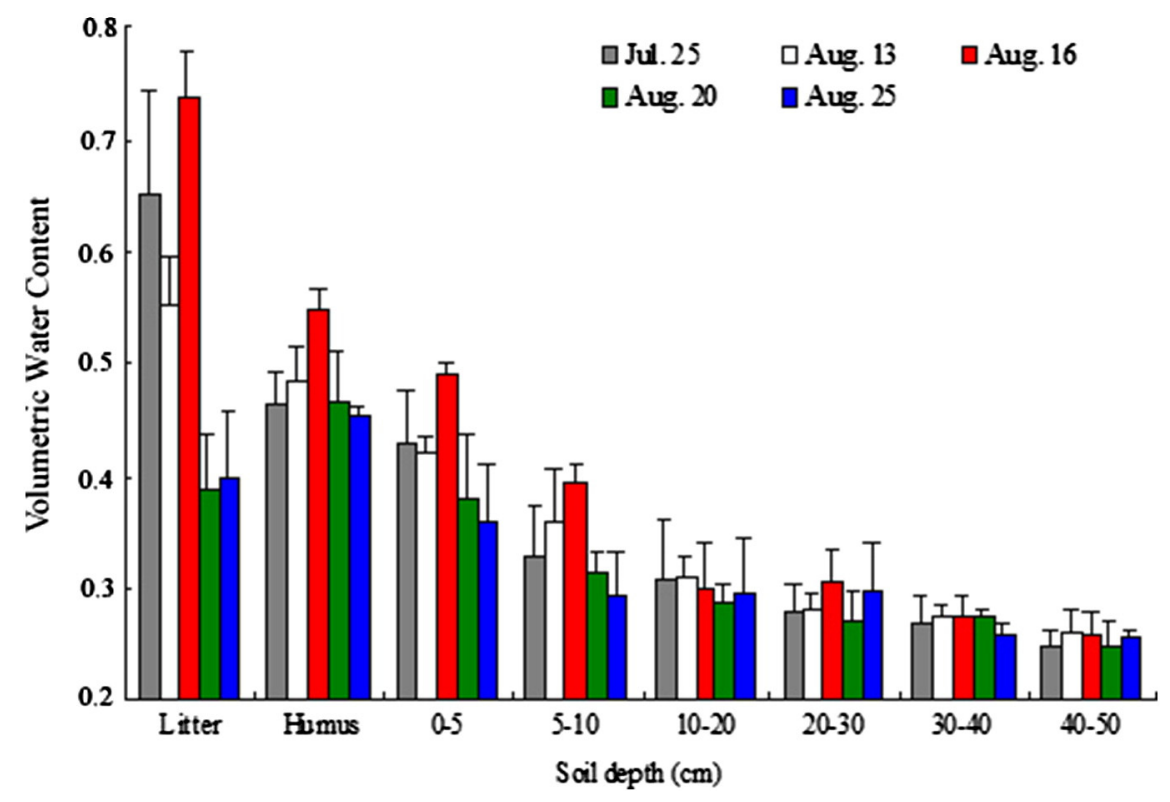

Fig. 2. Water content in soil columns on July 25, August 13, 16, 20, and 25, 2003. Each bar was an average of the same layer within three plots. 


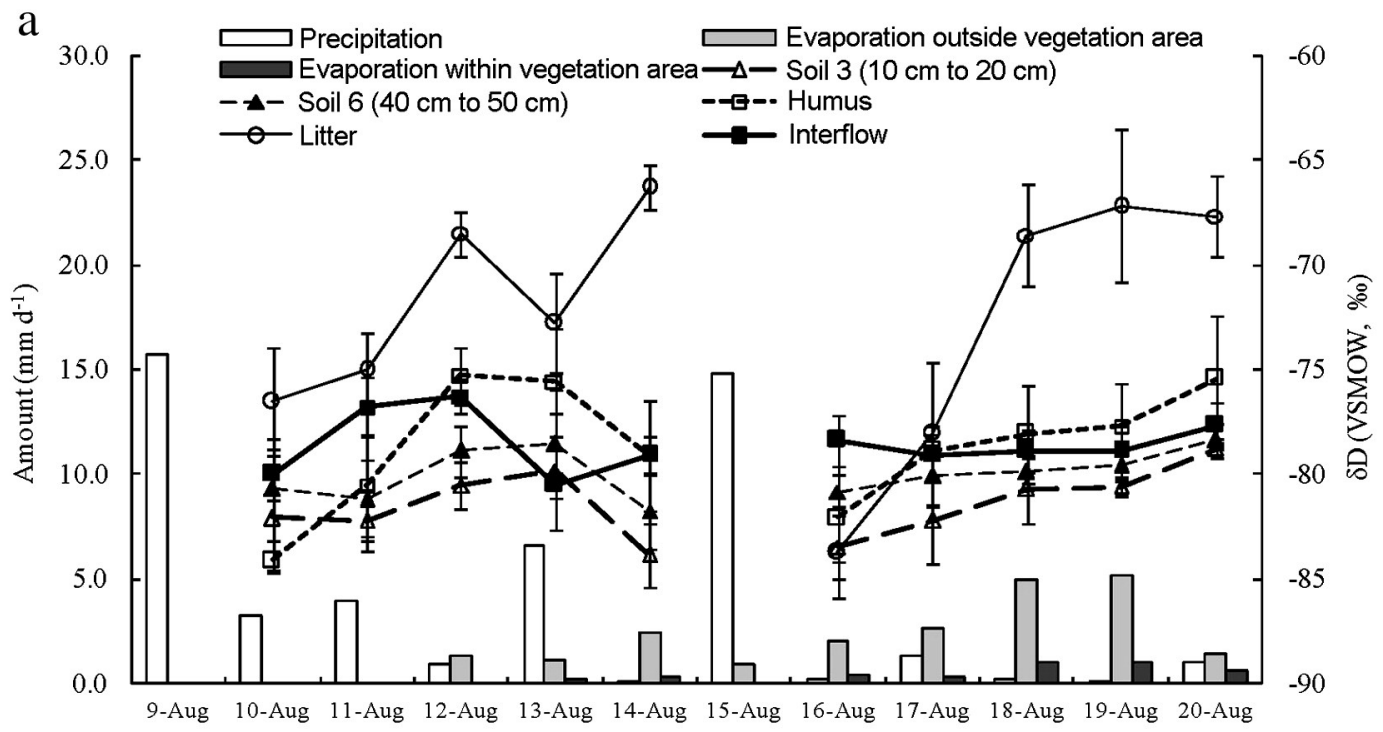

Date

b

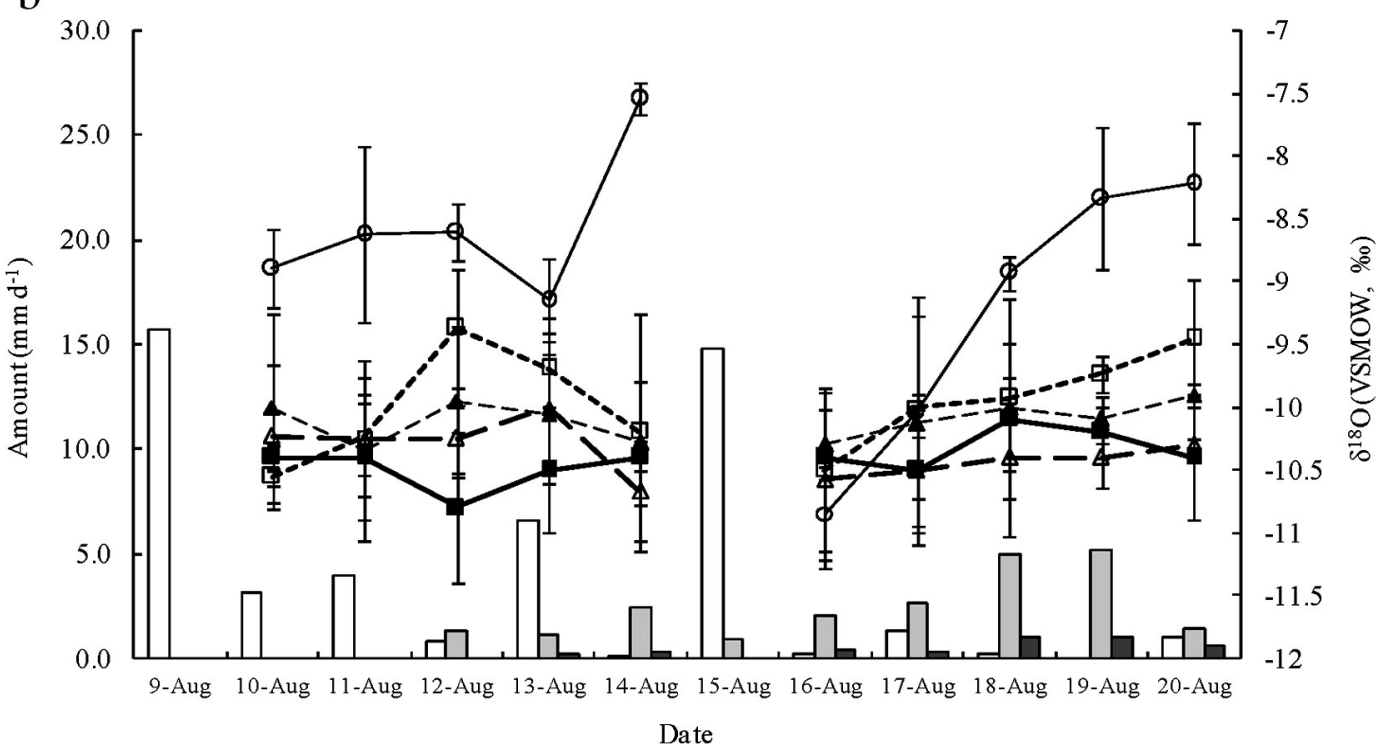

Fig. 3. Temporal changes of stable hydrogen (a) and oxygen (b) isotope ratios of litter, humus, and soil waters after rainfall events. Precipitation occurred on August 9 to $10,11,13$, and 15, 2003.

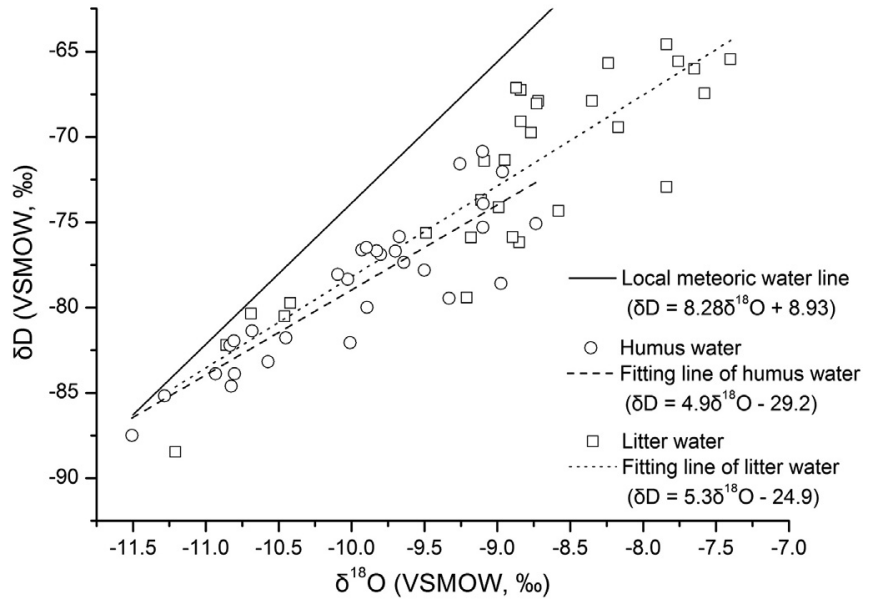

Fig. 4. Effects of evaporation on water isotopes of humus and litter in the space of $\delta \mathrm{D}$ versus $\delta^{18} \mathrm{O}$. Note: The local meteoric water line is $\delta \mathrm{D}=8.28 \delta^{18} \mathrm{O}+8.93$ (Liu et al., 2011a). constituted more of the stored water in Soil 3 and Soil 6 and approached $100 \%$ with consecutive days of rain at that rate.

\subsection{Effective contribution times of precipitation and throughfall to soil water}

Based on the assumptions of effective contribution time, precipitation of 4.0 to $18.9 \mathrm{~mm}$ remained in humus for 3 to 4 days, and in Soils 3 and 6 for 3 to 5 days. Mean effective contribution time of throughfall in those three layers was similar to that of precipitation (Fig. 7). Effects of precipitation and throughfall on soil water lasted no more than 5 days, and during these 5 days, water yields from soil were more obviously higher.

\section{Discussion}

\subsection{Movement of rainwater in shallow soil of shrubland}

In this study, we found that the spatial and temporal changes in water isotopes in humus and litter layers (Figs. 3 and 4) were caused 
a

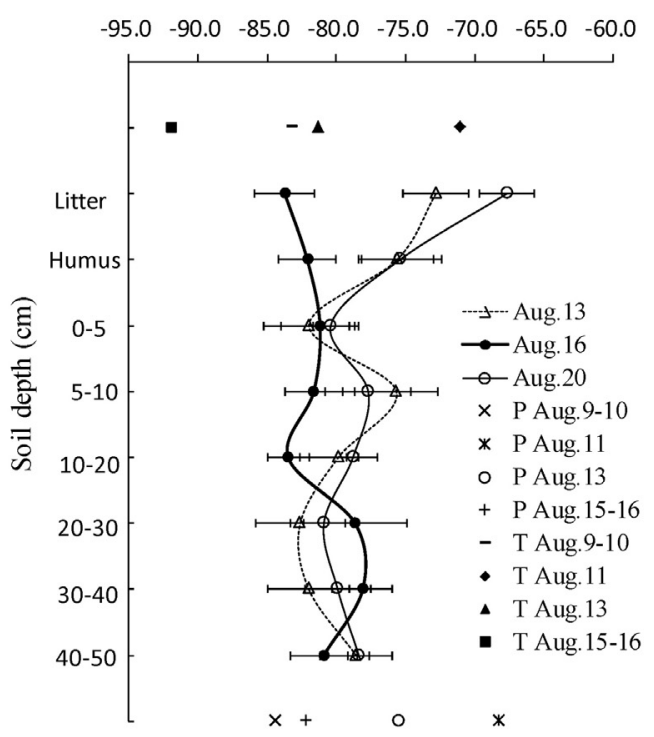

b

$\delta^{18} \mathrm{O}(\mathrm{VSMOW}, \%)$

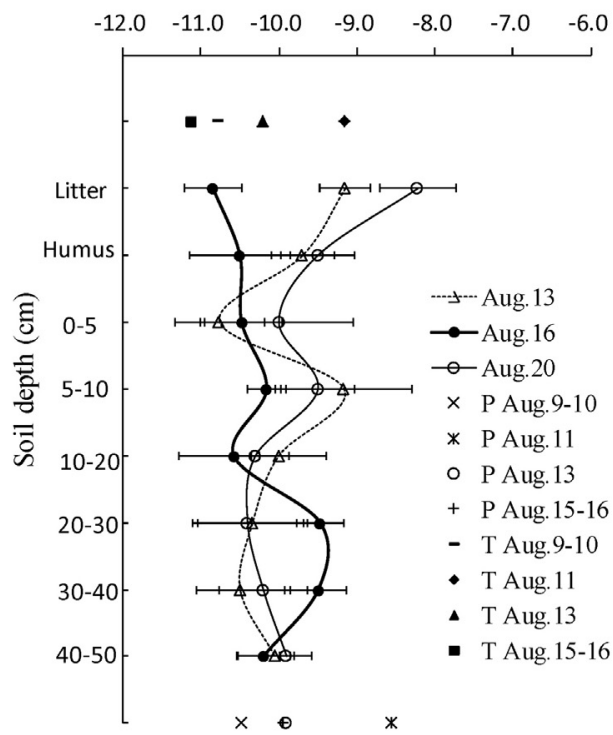

Fig. 5. Stable isotopic profiles of $\delta \mathrm{D}(\mathrm{a})$ and $\delta^{18} \mathrm{O}(\mathrm{b})$ in litter water and soil columns. P: precipitation; T: throughfall.

obviously by evaporation, which could enrich heavy isotopes in the rest of the rainwater (Acheampong and Hess, 2000; Gazis and Feng, 2004; Tang and Feng, 2001; Tian et al., 2002). This temporal trend of $\delta^{18} \mathrm{O}$ in the water of Soil 3 might also be affected by evaporation or enriched water pushed in by piston flow from upper layers (Kortelainen and
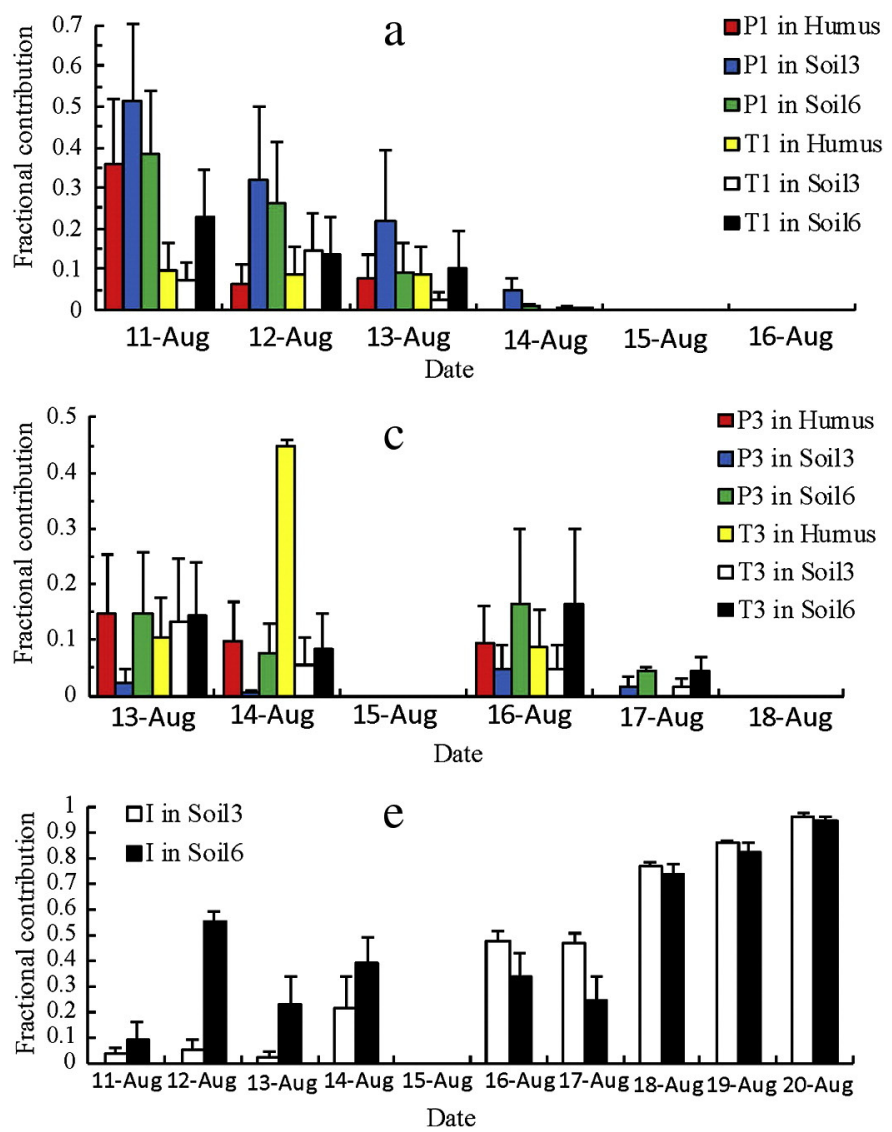

Karhu, 2004; Tang and Feng, 2001; Tian et al., 2002). In particular, the isotopic variations in different soil profiles $(0-50 \mathrm{~cm})$ could be explained by the ubiquitous existence of preferential flow in shallow soil systems (Gazis and Feng, 2004; Renshaw et al., 2003)) that could control the isotopic composition of soil water (Carreon-Diazconti et al.,
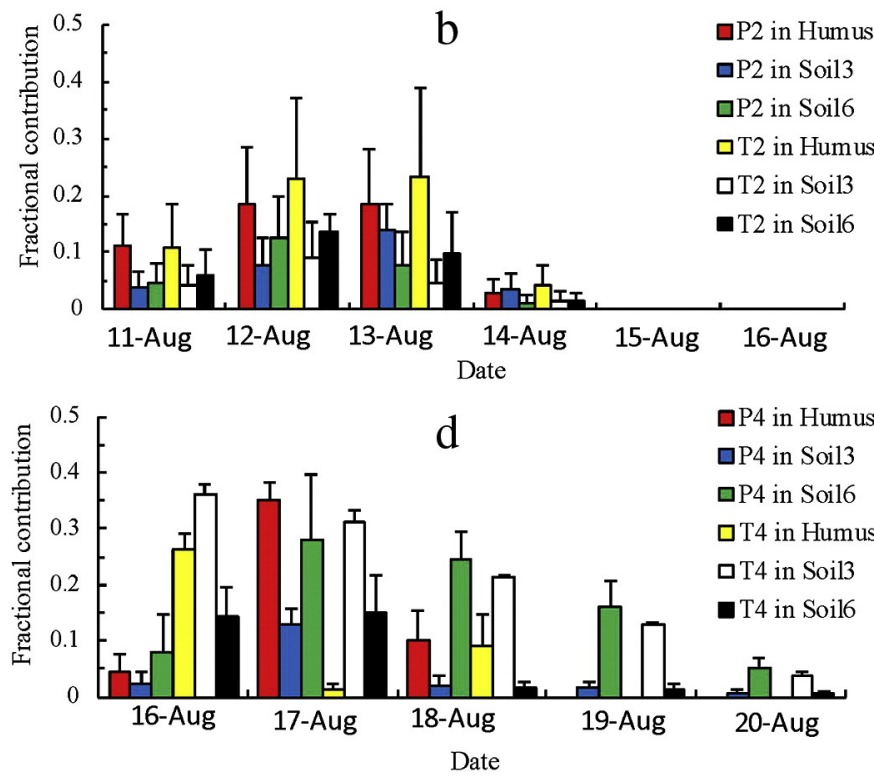

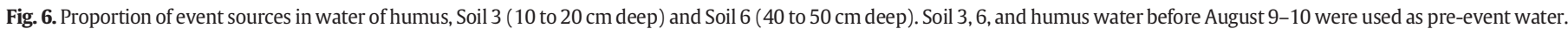

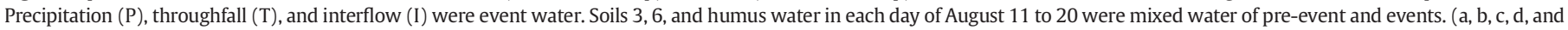

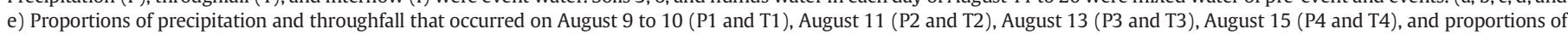
interflow in Soil 3 and Soil 6, respectively. No sample was collected on August 15 because a rain event lasted all day. 

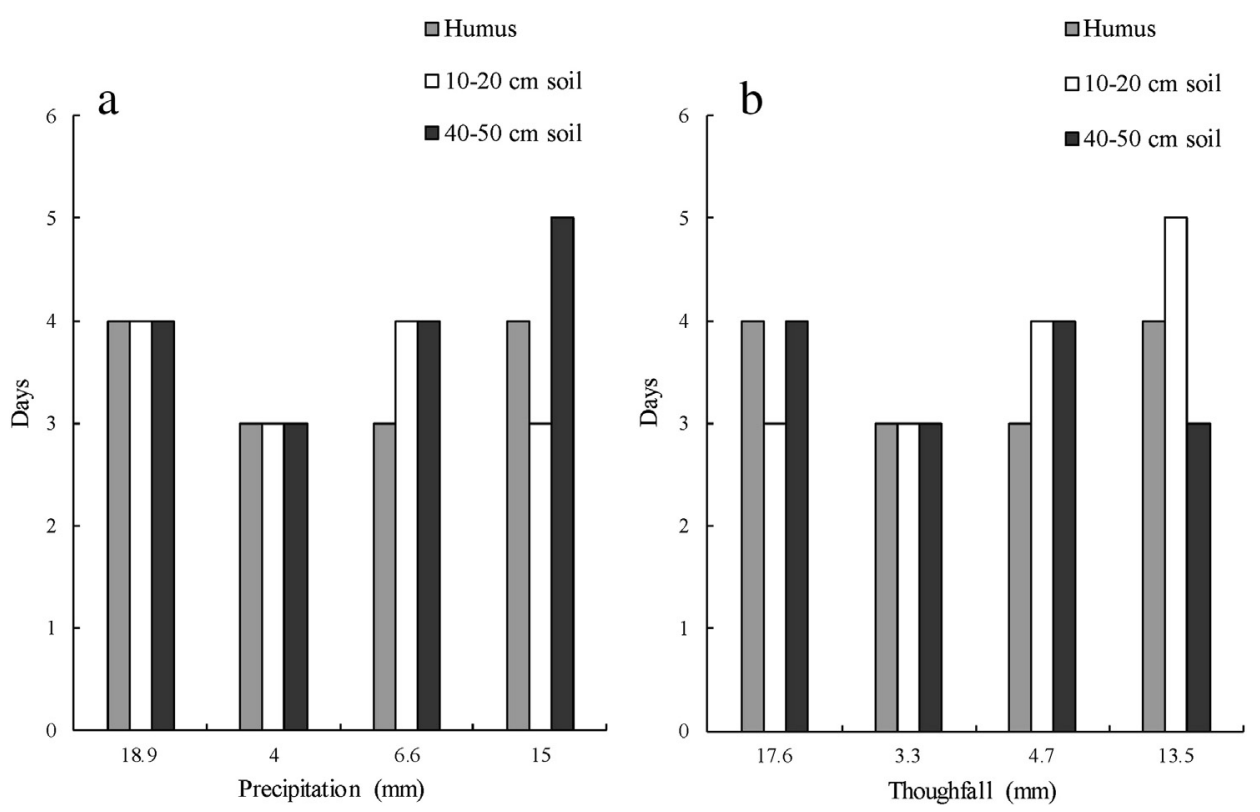

Fig. 7. Mean effective contribution times of precipitation and throughfall in humus, Soil 3 ( 10 to $20 \mathrm{~cm}$ deep), and Soil 6 ( 40 to $50 \mathrm{~cm}$ deep).

2003; Gazis and Feng, 2004). Proportional contributions in our study showed that small precipitation events could also reach soil depths of $40-50 \mathrm{~cm}$ and effectively replace older water in shrub soil. This result agrees with the outcome of the study of He et al. (2004), who found that a small amount of precipitation $\left(<10 \mathrm{~mm} \mathrm{~d}^{-1}\right)$ could recharge soil water $50 \mathrm{~cm}$ deep on the south slope of this same study site. Renshaw et al. (2003) and Gazis and Feng (2004) found that this soil water recharge was mainly affected by preferential flow. Moreover, from August 9 to 20, the amount of evaporation within the vegetation area and total precipitation amounts were 3.8 and $48.1 \mathrm{~mm}$, respectively (Fig. 3); thus, a considerable amount of rainwater entered shrub soil, and evapotranspiration had only a small impact on soil water recharge. In unsaturated soil columns, preferential flow was dominant when the water content was low with little or no precipitation (Padilla et al., 1999). Variation of water isotopic values within the upper layers of the shrub floor (litter, humus, and upper soil layers $<20 \mathrm{~cm}$ deep) corresponds with that of precipitation (Fig. 3); this further proves that precipitation input infiltrated rapidly by the means of preferential flow (Gazis and Feng, 2004; Tian et al., 2002). Although interflow seeps that we collected were all far from the plots (more than $50 \mathrm{~m}$ away), interflow proportions in the water of Soils 3 and 6 (Fig. 6e) showed that interflow water was the main supplier of soil water, especially during non-rainy days. Therefore, ubiquitously lateral and vertical preferential flow in this mountain area was the main method of water recharge for soil water in soil columns in our study sites.

\subsection{Effective contribution time of precipitation, throughfall and runoff generation}

The mean effective contribution times of precipitation and throughfall to soil water ( 0 to $50 \mathrm{~cm}$ deep) in this mountainous region were relatively short and ranged from 3 to 5 days (Fig. 5), according to source contribution calculations (Fig. 4a, b, c, and d). DeWalle et al. (1997) and McGuire et al. (2002) found that the mean residence times of soil water at depths of 20 to $100 \mathrm{~cm}$ on flat ground ranged from 0.4 to 4 months. Asano et al. (2002) estimated mean residence times of from 4 to 27 days for soil water in steep un-channeled catchments of mountains. Although our contribution times were different based on the definition of their mean residence times, our results were comparable to the results of Asano et al. (2002). Mean residence times of soil water for hydrological inputs, precipitation, and throughfall could be affected by rain event size (Sala et al., 1981) and variable water content in unsaturated soil (McDonnell and Buttle, 1998), preferential flow in soil profiles (Gazis and Feng, 2004), and landforms. In our sites, average water content of soil ( 0 to $50 \mathrm{~cm}$ deep) were less than saturation volumetric water content $(0.47,0.42$, and 0.43 with depths of $0-20,20-40$, and $<40 \mathrm{~cm}$ in soil columns near Plot C, respectively) (Li et al., 2006). In addition, high soil capillarity porosity led to rapid travel times of infiltrated rain water, especially at soil depths $<40 \mathrm{~cm}$ (steady infiltration rate $>6.0 \mathrm{~mm} / \mathrm{min}$, Table 1). Moreover, slopes of most places in our study sites were more than $30^{\circ}$ (WNRAB, 1987), and fieldwork indicated interflow occurred during the sampling period, even on non-rainy days. Therefore, most rainwater resided transitorily in shallow soil water system in the hillslope covered with $Q$. aquifolioides during the rainy season.

On Balang Mountain, most precipitation events occur at intensity $<5 \mathrm{~mm} \mathrm{~d}^{-1}$ during the rainy season (Li et al., 2006). Preferential flows could be dominant in unsaturated soil columns (Padilla et al., 1999; Renshaw et al., 2003), so that their mixing with soil matrix water was avoided in transiently saturated areas (Uchida et al., 2003). In addition, runoff increased rapidly even when only small precipitation events had occurred (Renshaw et al., 2003). Therefore, preferential flow in our study sites also affected mean effective contribution time of rainwater in soil.

Based on the above discussion, rapid discharge of precipitation and throughfall by preferential flow and other soil characteristics decreased mean effective contribution time of rainwater in soil and promoted increased runoff in the mountainous region covered by $Q$. aquifolioides after 3 days of rain. In this region, Liu et al. (2011a, 2011b) found that higher alpine shrub-meadow coverage is associated with higher tributary water yield when all subwatersheds are dominated by two vegetation types (subalpine forest and alpine shrub-meadow) that influence water yields in opposite ways. This finding was confirmed by our shorter mean effective contribution time of rainwater to soil water.

\section{Conclusions}

We analyzed soil water dynamics by studying isotopic time series of soil water and correlative water sources. Precipitation and canopy throughfall were primary suppliers of water to humus and shallow 
soil (0 to $50 \mathrm{~cm}$ deep) during four precipitation events $\left(>3 \mathrm{~mm} \mathrm{~d}^{-1}\right)$, which comprised $60 \%$ water in these layers shortly after precipitation events. Water from small precipitation events (about $4.0 \mathrm{~mm} \mathrm{~d}^{-1}$ ) could also reach soil 40 to $50 \mathrm{~cm}$ deep based on calculations of the contributions of sources. The remainder of soil water was derived from older soil water and interflow. During non-rainy days, interflow comprised $96 \%$ water in soil columns. Even when large precipitation events (15.0 and $18.9 \mathrm{~mm}$ ) occurred, the mean effective contribution recharge time in soil ( 0 to $50 \mathrm{~cm}$ deep) was from 3 to 5 days. Preferential flow occurred in soil columns, as shown by undulating changes in soil water isotopic profiles. In addition, lateral preferential flow paths helped recharge soil water through interflow.

\section{Acknowledgments}

This study was supported by the National Key Basic Research Special Funds, People's Republic of China (No. 2002CB111504, 2014CB138802), the National Key Technology R\&D Program (No. 2011BAC02B03), and the National Natural Science Funds, People's Republic of China (Nos. 31370474,31060076 , and 40901029). Special thanks are also extended to the anonymous reviewers for their very helpful comments and suggestions.

\section{References}

Acheampong, S.Y., Hess, J.W., 2000. Origin of the shallow groundwater system in the southern Voltaian Sedimentary Basin of Ghana: an isotopic approach. J. Hydrol. 233, 37-53.

Asano, Y., Uchida, T., Ohte, N., 2002. Residence times and flow paths of water in steep unchannelled catchments, Tanakami, Japan. J. Hydrol. 261, 173-192.

Brown, V.A., McDonnell, J.J., Burns, D.A., Kendall, C., 1999. The role of event water, a rapid shallow flow component, and catchment size in summer stormflow. J. Hydrol. 217 (3-4), 171-190.

Cane, G., Clark, I.D., 1998. Tracing ground water recharge in an agricultural watershed with isotopes. Ground Water 37 (1), 133-139.

Carreon-Diazconti, C., Nelson, S.T., Mayo, A.L., Tingey, D.G., Smith, M., 2003. A mixed groundwater system at Midway, UT: discriminating superimposed local and regional discharge. J. Hydrol. 273, 119-138.

Cheng, X.L., An, S.Q., Li, B., Chen, J.Q., Lin, G.H., Liu, Y.H., Luo, Y.Q., Liu, S.R., 2006. Summer rain pulse size and rainwater uptake by three dominant desert plants in a desertified grassland ecosystem in northwestern China. Plant Ecol. 184, 1-12.

DeWalle, D.R., Edwards, P.J., Swistock, B.R., Aravena, R., Drimmie, R.J., 1997. Seasonal isotope hydrology of three Appalachian forest catchments. Hydrol. Process. 11, 1895-1906.

Dusek, J., Vogel, T., Sanda, M., 2012. Hillslope hydrograph analysis using synthetic and natural oxygen-18 signatures. J. Hydrol. 475, 415-427.

Ehleringer, J.R., Roden, J., Dawson, T.E., 2000. Assessing ecosystem-level water relations trough stable isotope ratio analysis. In: Sala, O.E., Jackson, R.B., Mooney, H.A., Howarth, R.W. (Eds.), Methods in Ecosystem Science. Springer, New York, pp. 181-198.

Gat, J.R., 1996. Oxygen and hydrogen isotopes in the hydrologic cycle. Annu. Rev. Earth Planet. Sci. 24, 225-262.

Gazis, C., Feng, X.H., 2004. A stable isotope study of soil water: evidence for mixing and preferential flow paths. Geoderma 119, 97-111.

Ghodrati, M., Chendorain, M., Chang, Y.J., 1999. Characterization of macropore flow mechanisms in soil by means of a split macropore column. Soil Sci. Soc. Am. J. 63, 1093-1101.

Girard, P., Hillaire-Marcel, C., Oga, M.S., 1997. Determining the recharge mode of Sahelian aquifers using water isotopes. J. Hydrol. 197, 189-202.

He, Q.H., He, Y.H., Bao, W.K., 2004. Dynamics of soil water contents on south-facing slope of dry valley area in the upper reaches of the Minjiang River. Chin. J. Appl. Environ. Biol. 10 (1), 68-74 (in Chinese with English abstract).

Hsieh, J.C.C., Chadwick, O.A., Kelly, E.F., Savin, S.M., 1998. Oxygen isotopic composition of soil water: quantifying evaporation and transpiration. Geoderma 82, 269-294.

Klaus, J., Zehe, E., Elsner, M., Kulls, C., McDonnell, J.J., 2013. Macropore flow of old water revisited: experimental insights from a tile-drained hillslope. Hydrol. Earth Syst. Sci. $17,103-118$
Kortelainen, N.M., Karhu, J.A., 2004. Regional and seasonal trends in the oxygen and hydrogen isotope ratios of Finnish groundwaters: a key for mean annual precipitation. J. Hydrol. 285, 143-157.

Landon, M.K., Delin, G.N., Komor, S.C., Regan, C.P., 2000. Relation of pathways and transit times of recharge water to nitrate concentrations using stable isotopes. Ground Water 38 (3), 381-395.

Langner, H.W., Gaber, H.M., Wraith, J.M., Huwe, B., Inskeep, W.P., 1999. Preferential flow through intact soil cores: effects of matric head. Soil Sci. Soc. Am. J. 63, 1591-1598.

Lennartz, B., Kamra, S.K., 1998. Temporal variability of solute transport under vadose zone conditions. Hydrol. Process. 12, 1939-1949.

Li, Z.X., Ouyang, Z.Y., Zheng, H., Liu, X.L., Su, Y.M., 2006. Comparison of rainfall redistribution in two ecosystems in Minjiang upper catchments, China. J. Plant Ecol. 30 (5), 723-731 (in Chinese with English abstract).

Liu, Y.H., Xu, Z., Duffy, R., Chen, W.L., An, S.Q., Liu, S.R., Liu, F.D., 2011a. Analyzing relationships among water uptake patterns, rootlet biomass distribution and soil water content profile in a subalpine shrubland using water isotopes. Eur. J. Soil Biol. 47, 380-386.

Liu, Y.H., Leng, X., Deng, Z.F., Wang, L.X., Zhang, L., Liu, S.R., An, S.Q., 2011b. Effects of watershed vegetation on tributary water yields during the wet season in the Heishui Valley, China. Water Resour. Manag. 25, 1449-1464.

McDonnell, J.J., Buttle, J.M., 1998. Comment on “A deterministic-empirical model of the effect of the capillary-fringe on near-stream area runoff. 1. Description of the model" by Jayatilaka CJ and Gillham RW (Journal of Hydrology vol. 184 (1996) 299-315). Journal of Hydrology 207 (3-4), 280-285.

McGuire, K.J., McDonnell, J.J., 2006. A review and evaluation of catchment transit time modeling. J. Hydrol. 330 (3-4), 543-563.

McGuire, K.J., DeWalle, D.R., Gburek, W.J., 2002. Evaluation of mean residence time in subsurface waters using oxygen-18 fluctuations during drought conditions in the mid-Appalachians. J. Hydrol. 261, 132-149.

McGuire, K.J., Weiler, M., McDonnell, J.J., 2007. Integrating tracer experiments with modeling to assess runoff processes and water transit times. Adv. Water Resour. 30 (4), 824-837.

Padilla, I.Y., Yeh, T.C.J., Conklin, M.H., 1999. The effect of water content on solute transport in unsaturated porous media. Water Resour. Res. 35, 3303-3313.

Phillips, D.L., Gregg, J.W., 2001. Uncertainty in source partitioning using stable isotopes. Oecologia 127, 171-179.

Phillips, D.L., Gregg, J.W., 2003. Source partitioning using stable isotopes: coping with too many sources. Oecologia 136, 261-269.

Renshaw, C.E., Feng, X., Sinclair, K.J., Dums, R.H.R., 2003. The use of stream flow routing for direct channel precipitation with isotopically-based hydrograph separations: the role of new water in stormflow generation. J. Hydrol. 273, 205-216.

Ridolfi, L., D'Odorico, P., Porporato, A., Rodriguez-Iturbe, I., 2003. Stochastic soil moisture dynamics along a hillslope. J. Hydrol. 272, 264-275.

Rosen, M.R., Bright, J., Carran, P., Stewart, M.K., Reeves, R., 1999. Estimating rainfall recharge and soil water residence times in Pukekohe, New Zealand, by combining geophysical, chemical, and isotopic methods. Ground Water 37 (6), 836-844.

Sala, O.E., Lauenroth, W.K., Parton, W.J., Trlica, M.J., 1981. Water status of soil and vegetation in a shortgrass steppe. Oecologia 48, 327-331.

Seyfried, M.S., Rao, P.S.C., 1987. Solute transport in undisturbed columns of an aggregated tropical soil: preferential flow effects. Soil Sci. Soc. Am. J. 51, 1434-1444.

Stumpp, C., Maloszewski, P., 2010. Quantification of preferential flow and flow heterogeneities in an unsaturated soil planted with different crops using the environmental isotope $\mathrm{d}^{18}$ O. J. Hydrol. 394, 407-415.

Tang, K.L., Feng, X.H., 2001. The effect of soil hydrology on the oxygen and hydrogen isotopic compositions of plants' source water. Earth Planet. Sci. Lett. 185, 355-367.

Tian, L.D., Yao, T.D., Tsujimura, M., Sun, W.Z., 2002. Stable isotope in soil water in the middle of Tibet plateau. Acta Pedol. Sin. 39 (3), 289-295 (in Chinese with English abstract).

Uchida, T., Asano, Y., Ohte, N., Mizuyama, T., 2003. Analysis of flowpath dynamics in a steep unchannelled hollow in the Tanakami Mountains of Japan. Hydrol. Process. $17,417-430$.

Uchida, T., Van Meerveld, I.T., McDonnell, J.J., 2005. The role of lateral pipe flow in hillslope runoff response: an intercomparison of non-linear hillslope response. J. Hydrol. 311 (1-4), 117-133.

Uchida, T., McDonnell, J.J., Asano, Y., 2006. Functional intercomparison of hillslopes and small catchments by examining water source, flowpath and mean residence time. J. Hydrol. 327 (3-4), 627-642.

Wang, X.F., Yakir, D., 2000. Using stable isotopes of water in evapotranspiration studies Hydrol. Process. 14, 1407-1421.

Weiler, M., McDonnell, J.J., 2004. Virtual experiments: a new approach for improving process conceptualization in hillslope hydrology. J. Hydrol. 285 (1-4), 3-18.

Wolong Nature Reserve Administration Bureau (WNRAB), 1987. Wolong Vegetation and Resource Plants. Sichuan Science and Technology Press, Chengdu (in Chinese). 